Jurnal Ilmiah "Kreatif" Vol. 18 No. 1 Januari 2020

"Jurnal Studi Pemikiran Pendidikan Agama Islam"

\title{
BIMBINGAN KONSELING DAN IMPLEMENTASINYA DALAM PENDIDIKAN ISLAM
}

\author{
Oleh: Sri Jamilah ${ }^{\star}$
}

\begin{abstract}
Abstrak
Islam merupakan sumber utama dalam membentuk pribadi seorang muslim yang baik. Dengan berlandasankan Al-Qur'an dan AsSunnah, Islam mengarahkan dan membimbing manusia ke jalan yang diridhoi oleh Allah SWT dengan membentuk kepribadian yang berakhlak karimah. Sebagaimana sabda Rasulullah SAW: sesungguhnya aku diutus untuk menyempurnakan akhlak yang mulia. Nabi diutus oleh Allah untuk membimbing dan mengarahkan manusia kearah kebaikan yang hakiki dan juga sebagai figur konselor yang sangat mumpuni dalam memecahkan berbagai permasalahan yang berkaitan dengan jiwa manusia agar manusia terhindar dari segala sifat-sifat yang negatif. Oleh karena itu, manusia diharapkan dapat saling memberikan bimbingan sesuai dengan kapasitasnya, sekaligus memberikan konseling agar tetap sabar dan tawakkal dalam menghadapi perjalanan kehidupan yang sebenarnya. Dengan pendekatan Islami, maka pelaksanaan konseling akan mengarahkan klien kearah kebenaran dan juga dapat membimbing dan mengarahkan hati, akal dan nafsu manusia untuk menuju kepribadian yang berkhlak karimah yang telah terkristalisasi oleh nilai-nilai ajaran Islam. Dan hal ini perlu diperhatikan oleh seorang guru untuk menunjang kesuksesan pendidikan Islam di sekolah maupun madrasah dalam melaksanakan bimbingan dan konseling untuk mengentaskan berbagai permasalahan yang dihadapi oleh peserta didik serta mengarahkannya untuk membentuk insan kamil yang memiliki kepribadian berakhlak karimah.
\end{abstract}

Kata Kunci: Bimbingan, Konseling, Islam, Pendidikan Islam.

\section{Pendahuluan}

Terkadang guru merasa siswa merupakan bagian terpenting dalam dirinya tidak hanya sebagai siswa tetapi lebih dari itu, sehingga perlu diberikan bimbingan dan penyuluhan yang lebih untuk membantu siswa mengembangkan potensi dirinya, dimana potensi sebagai rahmat

*Penulis adalah Dosen Tetap STAI Muhammadiyah Bima 
Jurnal Ilmiah "Kreatif" Vol. 18 No. 1 Januari 2020

"Jurnal Studi Pemikiran Pendidikan Agama Islam"

Tuhan Yang Maha Esa yang telah dibawa sejak lahir sebagai dari kombinasi genetika atau warisan dari ayah dan ibunya.

Guru bimbingan dan konseling (BK) dalam setiap pertemuan dengan siswa diharapkan meluangkan waktu untuk memberikan pengarahan dan perhatian sebagai bentuk estafet bimbingan karena bimbingan ini tidak menunggu siswa mengalami satu permasalahan akan tetapi lebih jauh dari itu untuk menanggulangi permasalahan muncul dan menjadi besar, sehingga dalam penyelesaian sejak dini telah diantisipasi.

Undang-undang system pendidikan Nasional No. 20 Tahun 2003 pasal 3 dinyatakan bahwa pendidikan nasional berfungsi mengembangkan kemampuan dan membentuk watak serta peradaban bangsa yang bermartabat dalam rangka mencerdaskan kehidupan bangsa, yang bertujuan untuk berkembangnya potensi peserta didik agar menjadi manusia yang beriman dan bertaqwa terhadap Tuhan Yang Maha Esa, berakhlak mulia, sehat, berilmu, cakap, kreatif, mandiri dan menjadi warga Negara yang demokratis serta bertanggung jawab.

Sejalan dengan tujuan pendidikan nasional maka dirumuskan tujuan pendidikan yakni memberi bekal kemampuan kepada siswa untuk mengembangkan kehidupannya sebagai pribadi, anggota masyarakat, warga Negara dan umat manusia. Pendidikan dasar merupakan pondasi untuk pendidikan selanjutnya dan pendidikan nasional. Untuk itu asset suatu bangsa tidak hanya terletak pada sumber daya alam yang melimpah tetapi juga terletak sumber daya manusia yang berkualitas, maka diperlukan peningkatan sumber daya manusia Indonesia sebagai kekayaan Negara yang kekal dan sebagai investasi untuk mencapai kemajuan bangsa.

Saat ini keberadaan Bimbingan Konseling (BK), di sekolah sudah tampak lebih baik apabila dibandingkan dengan masa sebelumnya, pengakuan kearah pelayanan BK atau Konseling sebagai suatu profesi sudah semakin mengkristal terutama dari pemerintah dan profesi lainnya. Meskipun demikian, masih adanya persepsi negative tentang BK terutama tentang keberadaannya di sekolah dan madrasah dari para guru mata pelajaran, sebagai pengawas, Kepala Sekolah, para siswa, orang tua siswa, bahkan guru BK itu sendiri.

Dalam perspektif pendidikan nasional, bimbingan konseling merupakan bagian yang tidak bisa dilepaskan dari system pendidikan di sekolah yang bertujuan untuk membantu para siswa agar dapat mengembangkan dirinya secara optimal. Maka guru bimbingan konseling (BK) dalam setiap pertemuan dengan siswa diharapkan meluangkan waktu untuk memberikan pengarahan dan perhatian sebagai bentuk estafet bimbingan karena bimbingan ini tidak menunggu siswa 
Jurnal IImiah "Kreatif" Vol. 18 No. 1 Januari 2020

"Jurnal Studi Pemikiran Pendidikan Agama Islam"

mengalami satu permasalahan akan tetapi lebih jauh dari itu untuk menanggulangi permasalahan muncul dan menjadi besar, sehingga dalam penyelesaian sejak dini telah diantisipasi.

\section{Pengertian Bimbingan Konseling}

Bimbingan konseling secara etimologis berasal dari kata "Guidance " berasal dari kata kerja "to guide" yang artinya menujukkan, bimbingan, menuntun atau membantu, maka bimbingan secara umum dapat diartikan sebagai suatu bantuan atau tuntunan. Menurut istilah bimbingan adalah suatu proses membantu individu melalui usaha sendiri untuk menentukan dan mengembangkan kemempuannya agar memperoleh kebahagiaan probadi dan kemanfaatan sosial. ${ }^{1}$

Prayitno dan Erman mengemukakan bahwa bimbingan adalah proses pemberian bantuan yang dilakukan oleh orang yang ahli kepada seorang atau beberapa orang individu, baik anak-anak, remaja, maupun dewasa agar orang yang dibimbing dapat mengembangkan kemampuan dirinya sendiri dan mandiri dengan memanfaatkan kekuatan individu dan sarana yang ada dan dapat dikembangkan berdasarkan norma-norma yang berlaku. ${ }^{2}$

Sedangkan menurut Frank Parson dalam Prayitno, bimbingan adalah sebagai bantuan yang diberikan kepada individu untuk dapat memilih, mempersiapkan diri, dan memangku suatu jabatan serta mendapat kemajuan dalam jabatan yang dipilihnya itu. ${ }^{3}$

Berikut ini penulis memaparkan pengertian konseling menurut beberapa ahli, tujuannya untuk memberikan kemudahan pembaca dalam memahami dua kata yang memiliki fungsi yang sama tetapi berbeda makna dalam aplikasinya.

Secara etimologis, istilah konseling berasal dari bahasa Latin, yaitu " consilium" yang berarti " dengan " atau " bersama" yang dirangkai dengan " menerima" atau " memahami". Sedangkan dalam bahasa Anglo-Saxon, istilah konseling berasal dari "sellan" yang berarti "menyerahkan" atau "menyampaikan".

Menurut, Rohman Natawidjaja, mendifinisikannya bahwa konseling adalah satu jenis pelayanan yang merupakan bagian terpadu dari bimbingan. Konseling dapat diartikan sebagai hubungan timbal

1 Prayitno dan Amti Emran, Dasar-Dasar Bimbingan Dan Konseling, (Jakarta: Rineka Cipta, 1999), 3

${ }^{2}$ Ibid, 94

3 Prayitno dan Erman Amti, Dasar-dasar bimbingan dan konseling, (Jakarta: Rineka Cipta, 2009), 93

${ }^{4}$ Ibid, 99 
Jurnal Ilmiah "Kreatif" Vol. 18 No. 1 Januari 2020

"Jurnal Studi Pemikiran Pendidikan Agama Islam"

balik antara dua orang individu, di mana yang seorang (yaitu konselor) berusaha membantu yang lain (yaitu Konseli) untuk mencapai pengertian tentang dirinya sendiri dalam hubungan dengan masalah-masalah yang dihadapinya pada waktu yang akan datang. ${ }^{5}$

Menurut Williamson, Conseling diartikan sebagai suatu proses personalisasi dan individualisasi untuk membantu seseorang dalam mempelajari mata pelajaran di sekolah, ciri-ciri perilaku sebagai warganegara dan nilai-nilai pribadi dan social serta kebiasaan-kebiasaan dan semua kebiasaan lainnya, mempelajari keterampilan (skill), sikap, dan kepercayaan yang dapat membantu dirinya selaku makhluk yang dapat menyesuaikan diri secara normal. ${ }^{6}$

\section{Pendekatan Islami Dalam Pelaksanaan Bimbingan Konseling}

Pendekatan Islami dalam bimbingan dan konseling dapat dikaitkan dengan aspek-aspek psikologis yang meliputi pribadi, sikap, kecerdasan, perasaan dan lain-lain yang berkaitan dengan klien dan konselor. Bagi pribadi muslim yang berlandaskan tauhid, merupakan pribadi yang bekerja keras untuk melaksanakan tugas suci yang telah Allah berikan dan percayakan kepadanya, yang mana baginya merupakan suatu ibadah. Sehingga pada pelaksanaan bimbingan dan konseling, pribadi muslim berprinsip pada hal-hal sebagaimana yang disampaikan oleh Nelly Nurmelly dalam papernya peran agama dalam bimbingan konseling berikut ini:

a. Selalu memiliki prinsip landasan dan prinsip dasar yaitu hanya beriman kepada Allah swt.

b. Memiliki prinsip kepercayaan, yakni beriman kepada malaikat.

c. Memiliki prinsip kepemimpinan, yakni beriman kepada Nabi dan Rasul-Nya.

d. Selalu memiliki prinsip pembelajaran, yakni berprinsip pada AlQuran.

e. Memiliki prinsip masa depan, yakni beriman kepada hari akhir.

f. Memiliki prinsip keteraturan, yakni beriman kepada ketentuan Allah. ${ }^{7}$

Jika seorang konselor memegang prinsip tersebut, maka pelaksanaan bimbingan dan konseling akan mengarah kearah kebenaran,

${ }^{5}$ Dewa Ketut Sukardi dkk, Proses Bimbingan dan Konseling di Sekolah, (Jakarta: Rineka Cipta, 2008), 5

6 Arifin, Teori-teori Konseling Agama dan Umum, (Jakarta: Golden Terayon Press, 2003), 95

7 Nelly Nurmelly, Peran Agama Dalam Bimbingan dan Konseling, (Palembang: Widyaswara Muda, 2011), 99 
Jurnal Ilmiah "Kreatif" Vol. 18 No. 1 Januari 2020

"Jurnal Studi Pemikiran Pendidikan Agama Islam"

selanjutnya dalam pelaksanaan Bimbingan dan Konseling perlu memiliki tiga langkah untuk mewujudkan tujuannya. Pertama, memiliki mission statement yang jelas yaitu daua kalimat syahadat. Kedua, memiliki sebuah metode pembangunan karakter sekaligus simbol kehidupan yaitu shalat lima waktu. Ketiga, memiliki kemampuan pengendalian diri yang dilatih dan disimbolkan dengan puasa. Dengan prinsip tersebut, seorang konselor dapat menghasilkan kecerdasan emosi dan spiritual (ESQ) yang sangat tinggi (Akhlakul Karimah). Selain itu seorang konselor juga perlu mengetahhui pandangan filsafat Ketuhanan (Teologi) karena manusia sejatinya telah membawa potensi bertuhan sejak dilahirkan. Dalam menghadapi masalah diarahkan dengan pendekatan agama. Yang mana dalam agama mempunyai fungsi-fungsi pelayanan bimbingan, konseling dan terapi yang didasarkan kepada Al-Quran dan As-sunnah. Dan sudah pastinya, pelaksanaan bimbingan dan konseling ddengan pendekatan agama Islam, akan membawa kepada peningkatan iman, ibadah dan jalan yang diridhai Allah swt.

Dalam menghadapi berbagai permasalahan yang dihadapi manusia, agama telah mengatur berbagai aspek kehidupan manusia untuk mewujudkan rasa damai dan tentram bagi jiwa manusia dalam menuju kebahagiaan yang hakiki. Peranan agama Islam dalam menghadapi kesehatan mental manusia adalah sebagaimana berikut:

a. Ajaran Islam beserta seluruh petunjuknya yang ada di dalamnya merupakan obat bagi jiwa atau penyembuh segala penyakit hati yang terdapat dalam jiwa manusia.

b. Ajaran Islam memberikan bantuan kejiwaan kepada manusia dalam menghadapi cobaan dan mengatasi kesulitan.

c. Ajaran Islam memberikan rasa aman dan tentram yang menimbulkan keimanan kepada allah dalam jiwa seorang mukmin.

Bagi seorang mukmin, ketenangan jiwa, rasa aman dan ketentraman jiwa akan terealisasi dengan keimanannyakepada Allah yang akan membekali harapan akan pertolongan, lindungan dan penjagaan-Nya.

\section{Teori-Teori Konseling dalam Islam}

Yang dimaksud dengan teori-teori konseling dalam Islam adalah landasan yang benar dalam melaksanakan proses bimbingan dan konseling agar dapat berlangsung dengan baik dan menghasilkan perubahan-perubahan positif bagi klien mengenai cara dan paradigma berfikir, cara menggunakan potensi nurani, cara berperasaan, cara berkeyakinan dan cara bertingkah laku berdasarkan Al-Quran dan AsSunnah. 
Jurnal Ilmiah "Kreatif" Vol. 18 No. 1 Januari 2020

"Jurnal Studi Pemikiran Pendidikan Agama Islam"

Allah berfirman dalam Al-Quran: "Serulah (manusia) kepada jalan Tuhan-mu dengan hikmah dan pelajaran yang baik dan bantahlah mereka dengan cara yang baik. Sesungguhnya Tuhanmu Dialah yang lebih mengetahui tentang siapa yang tersesat dari jalan-Nya dan Dialah yang lebih mengetahui orang-orang yang mendapat petunjuk." (An-Nahl (16): 125). Ayat tersebut menjelaskan beberapa teori atau metode dalam pelaksanaan bimbingan dan konseling. Teori-teori tersebut sebagaimana yang telah dipaparkan oleh Hamdani Bakran, sebagai berikut:

a. Teori Al-Hikmah

Sebuah pedoman, penuntun dan pembimbing untuk memberi bantuan kepada individu yang sangat membutuhkan pertolongan dalam mendidik dan mengembangkan eksistensi dirinya hingga ia dapat menemukan jati diri dan citra dirinya serta dapat menyelesaikan atau mengatasi berbagai permasalahan hidup secara mandiri. Proses aplikasi konseling teori ini semata-mata dapat dilakukan oleh konselor dengan pertolongan Allah, baik secara langsung maupun melalui perantara, dimana ia hadir dalam jiwa konselor atas izin-Nya.

b. Teori Al-Mauidhoh Hasanah

Yaitu teori bimbingan atau konseling dengan cara mengambil pelajaran-pelajaran dari perjalanan kehidupan para Nabi dan Rasul. Bagaimana Allah membimbing dan mengarahkan cara berfikir, cara berperasaan, cara berperilaku serta menanggulangi berbagai problem kehidupan. Bagaimana cara mereka membangun ketaatan dan ketaqwaan kepada-Nya. Yang dimaksud dengan Al-Mau'izhoh Al-Hasanah ialah pelajaran yang baik dalam pandangan Allah dan Rasul-Nya, yaitu dapat membantu klien untuk menyelesaikan atau menanggulangi problem yang sedang dihadapinya.

c. Teori Mujadalah yang baik

Yang dimaksud teori Mujadalah ialah teori konseling yang terjadi dimana seorang klien sedang dalam kebimbangan. Teori ini biasa digunakan ketika seorang klien ingin mencari suatu kebenaran yang dapat menyakinkan dirinya, yang selama ini ia memiliki problem kesulitan mengambil suatu keputusan dari dua hal atau lebih; sedangkan ia berasumsi bahwa kedua atau lebih itu lebih baik dan benar untuk dirinya. Padahal dalam pandangan konselor hal itu dapat membahayakan perkembangan jiwa, akal pikiran, emosional, dan lingkungannya. Prinsip-prinsip dari teori ini adalah sebagai berikut. 
Jurnal Ilmiah "Kreatif" Vol. 18 No. 1 Januari 2020

"Jurnal Studi Pemikiran Pendidikan Agama Islam"

1. Harus adanya kesabaran yang tinggi dari konselor;

2. Konselor harus menguasai akar permasalahan dan terapinya dengan baik;

3. Saling menghormati dan menghargai;

4. Bukan bertujuan menjatuhkan atau mengalahkan klien, tetapi membimbing klien dalam mencari kebenaran;

5. Rasa persaudaraan dan penuh kasih sayang;

6. Tutur kata dan bahasa yang mudah dipahami dan halus;

7. Tidak menyinggung perasaan klien;

8. Mengemukakan dalil-dalil Al-Qur'an dan As-Sunnah dengan tepat dan jelas;

9. Ketauladanan yang sejati. Artinya apa yang konselor lakukan dalam proses konseling benar-benar telah dipahami, diaplikasikan dan dialami konselor. Karena Allah sangat murka kepada orang yang tidak mengamalkan apa yang ia nasehatkan kepada orang lain. ${ }^{8}$

Dalam al-Qur'an surat Ash-Shaff: 2-3: "Wahai orang-orang yang beriman, mengapa kamu mengatakan apa yang tidak kamu perbuat?. Amat besar kebencian di sisi Allah bahwa kamu mengatakan apa-apa yang tiada kamu kerjakan."

Teori konseling "Al-Mujadalah bil Ahsan", menitikberatkan kepada individu yang membutuhkan kekuatan dalam keyakinan dan ingin menghilangkan keraguan terhadap kebenaran Ilahiyah yang selalu bergema dalam nuraninya. Seperti adanya dua suara atau pernyataan yang terdapat dalam akal fikiran dan hati sanubari, namun sangat sulit untuk memutuskan mana yang paling mendekati kebenaran.

\section{Teknik-tekning Konseling dalam Islam}

Konseling merupakan aktifitas untuk menciptakan perubahanperubahan dan perbaikan-perbaikan. Untuk mencapai tujuan yang diharapkan, ada perlunya dalam pelaksanaan bimbingan dan konseling membutuhkan teknik-teknik yang memadai. Berikut ini adalah beberapa teknik konseling sebagaimana yang telah disampaikan oleh Hamdani Bakari, yakni:

a. Teknik yang bersifat lahir

Teknik yang bersifat lahir ini menggunakan alat yang dapat di lihat, di dengar atau dirasakan oleh klien (anak didik) yaitu dengan menggunakan tangan atau lisan antara lain:

${ }^{8}$ Bakari, Hamdani, Konseling dan Psikoterapi Islam, (Yogyakarta: Fajar Pustaka, 2002), 
Jurnal Ilmiah "Kreatif" Vol. 18 No. 1 Januari 2020

"Jurnal Studi Pemiß̧iran Pendidikan Agama Islam"

1) Dengan menggunakan kekuatan, power dan otoritas

2) Keinginan, kesungguhan dan usaha yang keras

3) Sentuhan tangan (terhadap klien yang mengalami stres dengan memijit di bagian kepala, leher dan pundak)

4) Nasehat, wejangan, himbauan dan ajakan yang baik dan benar. Maksudnya dalam konseling, konselor lebih banyak menggunakan lisan yang berupa pertanyaan yang harus dijawab oleh klien dengan baik, jujur dan benar. Agar konselor bisa mendapatkan jawaban dan pernyataan yang jujur dan terbuka dari klien, maka kalimat yang dilontarkan konselor harus mudah dipahami, sopan dan tidak menyinggung perasaan atau melukai hati klien. Demikian pula ketika memberikan nasehat hendaklah dilakukan denagn kalimat yang indah, bersahabat, menenangkan dan menyenangkan.

5) Menbacakan do'a atau berdo'a dengan menggunakan lisan

b. Teknik yang Bersifat Batin

Yaitu teknik yng hanya dilakukan dalam hati dengan do'a dan harapan namun tidak usaha dan upaya yang keras secara konkrit, seperti dengan menggunakan potensi tangan dan lisan. Oleh karena itulah Rosululloh bersabda "bahwa melakukan perbuatan dan perubahan dalam hati saja merupakan selemah-lemahnya iman".

Teknik konseling yang ideal adalah dengan kekuatan, keinginan dan usaha yang keras dan sungguh-sungguh dan diwujudkan dengan nyata melalui perbuatan, baik dengan tangan, maupun sikap yang lain. Tujuan utamanya adalah membimbing dan mengantarkan individu (anak didik) kepada perbaikan dan perkembangan eksistensi diri dan kehidupannya baik dengan Tuhannya, diri sendiri, lingkungan keluarga, lingkungan pendidikan dan lingkungan masyarakat. ${ }^{9}$

\section{Implementasi Bimbingan Konseling dalam Pendidikan Islam}

Seperti halnya ilmu-ilmu yang lain bimbingan konseling juga memiliki implementasi dalam prosesnya, sehingga untuk memudahkan penulis memaparkan pengertian kata implementasi tersebut, dalam kamus Bahasa Indonesia, kata implementasi berarti "pelaksanaan atau penerapan". ${ }^{10}$ Artinya dilaksanakan dan diterapkan dalam kurikulum dan

\footnotetext{
${ }^{9}$ Bakari, Konseling..., 55

${ }^{10}$ Tim Penyusun Kamus PUsat Bahasa, Kamus Besar Bahasa Indonesia, (Jakarta: Balai Pustaka, 2007), 427
} 
Jurnal Ilmiah "Kreatif" Vol. 18 No. 1 Januari 2020

"Jurnal Studi Pemikiran Pendidikan Agama Islam"

peraturan yang telah dirancang atau didesain oleh para ahli atau tim perumus sekolah yang kemudian dapat dilaksanakan dengan baik sesuai dengan peraturan yang berlaku di sekolah, baik sekolah dasar maupun menengah.

Jadi, yang dimaksudkan penulis implementasi bimbingan konseling dalam pendidikan Islam adalah bagaimana cara guru pendidikan agama Islam dalam memberikan bimbingan konseling serta pelayanan dan solusi yang ditawarkan kepada para siswa yang mengalami masalah di sekolah atau kelas sehingga dapat diatasi sedini mungkin tanpa menimbulkan konflik yang berkepanjangan.

Implementasi bimbingan konseling dalam pendidikan agama Islam adalah sebagaimana yang telah dicontohkan oleh Rasulullah SAW, yang meliputi 1) uswatun hasanah (Akhlak/contoh yang baik), guru pendidikan agama Islam memberikan akhlak/contoh yang baik pada siswanya (ucapan, sikap, pakaian, kedisiplinan) seperti dalam menghadapi siswa yang bermasalah tidak langsung memberikan hukuman atau ganjaran atau kata-kata yang tidak mendidik atas kesalahan yang telah dilakukan akan tetapi lebih kepada diagnosa atau melihat lebih dalam terhadap permasalahan yang dihadapi siswa, lalu memberikan solusi dengan cara yang baik seperti memanggil siswa tersebut lalu memberikan nasehat dan masukan terhadap masalahnya, bila tidak mampu maka guru melibatkan orang lain yang dianggap mampu dalam masalah tersebut seperti kepala sekolah, komite atau wali murid. Sebagaimana sabda Rasulullah SAW, yang artinya " Sesunguhnya saya diutus untuk menyempurnakan akhlak yang mulia" (HR Ahmad, Baihaqi, dan Malik). ${ }^{11}$ 2) Matin al-Khuluk ( akhlak yang kokoh) dititik beratkan pada kejujuran, amanah, kasih sayang dan kedisiplinan, artinya guru memberikan contoh bila berkata harus jujur sesuai dengan kenyataan tidak mengarang cerita yang akhirnya ketahuan oleh siswa bahwa guru tersebut berbohong, amanah siswa adalah amanah yang dititpkan oleh orang tua kepada guru untuk dibimbing dan diberi pengarahan maka guru harus bertanggungjawab terhadap amanah tersebut sehingga orang tua siswa merasa diperhatikan, kasih sayang guru tidak hanya sebagai pendidik tetapi juga sebagai orang tua yang ada di sekolah maka kewajibannya adalah menyayangi siswa seperti anak sendiri tanpa harus memilih dari latar belakang siswa yang berbeda-beda, serta kedisiplinan guru menjadi bagian yang terpenting dalam menjalankan tugas membimbing sesuai dengan ajaran agama Islam yang mengajarkan umatnya untuk tepat waktu. 3) Qodirun Ala Al-

11 Ahmad Taufiq dan Muhammad Rohmadi, Pendidikan Agama Islam, Pendidikan Karakter berbasis Agama Islam (Yuma Pustaka, Surakarta, 2001), 29 
Jurnal Ilmiah "Kreatif" Vol. 18 No. 1 Januari 2020

"Jurnal Studi Pemikiran Pendidikan Agama Islam"

Kasbi (kemampuan untuk berusaha sendiri) siswa diberikan kegiatan yang kemudian dapat mereka kembangkan sendiri seperti membuat Bros yang bahan bakunya dari bahan yang sederhana sehingga mendapatkan pemasukan untuk uang jajan, mendapatkan bea siswa prestasi untuk modal usaha seperti jual pulsa dan sebagian untuk bayar kuliah dan keterampilan-keterampilan lainnya yang dapat menunjang kemandirian dini. $^{12}$

Fenomena yang banyak terjadi sekarang ini, hubungan gurumurid sudah banyak meninggalkan nilai-nilai keislaman, banyak guru yang tidak megenal murid-muridnya, dan yang lebih parah lagi murid yang tidak mengenal gurunya, akan tetapi islam memerintahkan umatnya untuk menyayangi, menghormati dan menempatkan murid dalam posisi yang tinggi. Sebagaimana hadis Rasulullah SAW "Barang siapa menempuh suatu jalan dalam rangka mencari ilmu, maka Allah akan memudahkan baginyajalan ke surga. Sesungguhnya malaikat merebahkan sayapnya karena ridho terhadap penuntut ilmu. Dan sesungguhnya orang yang berilmu, dosa-dosanya akan dimintakan ampun oleh siapa saja yang ada di langit dan di bumi termasuk ikan-ikan yang ada di air" ( HR abu Dawud dan Tirmizi). ${ }^{13}$

Pembahasan di atas menegaskan bahwa guru dan murid samasama mulia dan memiliki kedudukan yang khusus disisi Allah dan sisi manusia karena kedua-duanya mencintai ilmu. Karena itulah interaksi guru dan murid harus dalam koridor saling menghormati, saling menghargai dan saling menyayangi dan sepatutnya memiliki rasa kasih sayang dan peduli kepada muridnya dan murid menghormati guru.

\section{Simpulan}

Bimbingan dan konseling dalam Islam ialah suatu aktifitas memberikan bimbingan, pengajaran, dan pedoman kepada peserta didik yang dapat memngembangkan potensi akal pikiran, kejiwaan, keimanan dan keyakinannya serta dapat menanggulangi problematika dalam keluarga, sekolah dan masyarakat dengan baik dan benar secara mandiri berdasarkan Al-Qur'an dan Al-Hadis. Dengan menggunakan teknikteknik tertentu.

${ }^{12}$ Nur Rofiq, "Implementasi Nilai-Nilai Endidikan Agama Islam dalam bimbingan konseling di SMA 8 Semarang 2009/2010," Fakultas Tarbiyah, IAIN Walisongo, 2010.

13 Tobroni, Pendidikan Islam, Paradigma Teologis, Filosofis dan spiritualitas, (UMM Press, Malang, 2008), 111 
Jurnal Ilmiah "Kreatif" Vol. 18 No. 1 Januari 2020

"Jurnal Studi Pemikiran Pendidikan Agama Islam"

Tujuan bimbingan dan konseling dalam Islam adalah membantu individu mencegah timbulnya problem-problem yang berkaitan dengan kegiatan belajar / pendidikan, membantu individu dan membantu individu memelihara situasi dan kondisi kegiatan belajar agar tetap baik dan mengembangkannya menjadi lebih baik sesuai dengan alQur'an dan Hadist Nabi.

\section{Daftar Pustaka}

Arifin, Teori-teori Konseling Agama dan Umum, ( Golden Terayon Press, Jakarta, 2003) .

Ahmad Taufiq dan Muhammad Rohmadi, Pendidikan Agama Islam, Pendidikan Karakter berbasis Agama Islam (Yuma Pustaka, Surakarta, 2001).

Bakari, Hamdani. 2002. Konseling dan Psikoterapi Islam. Fajar Pustaka. Yogyakarta.

Dewa Ketut Sukardi dkk, Proses Bimbingan dan Konseling di Sekolah, ( Rineka Cipta, Jakarta, 2008).

Jamal Ma'mur Asmani, Bimbingan dan Konseling di Sekolah,(Diva Press,Jogjakarta, 2010).

Prayitno dan Amti Emran, Dasar-Dasar Bimbingan Dan Konseling, (Rineka Cipta, Jakarta 1999).

Prayitno dan Erman Amti, Dasar-dasar bimbingan dan konseling, (Rineka Cipta, Jakarta, II (Revisi), 2009) .

Nurmelly, Mely. 2011. Peran Agama Dalam Bimbingan dan Konseling. Widyaswara Muda bdk. Palembang.

Tobroni, Pendidikan Islam (Paradigma Teologis, Filosofis dan spiritualitas), (UMM Press, Malang, 2008)

Tim Penyusun Kamus PUsat Bahasa. 2007. KBBI. (Jakarta,Balai Pustaka)

Nur Rofiq, Implementasi nilai-nilai endidikan agama Islam dalam bimbingan konseling di SMA 8 Semarang 2009/2010. (Fakultas Tarbiyah, IAIN Walisongo, 2010.( 14 Januari 2016) 